\title{
ANALISIS RASIO PROFITABILITAS DALAM MEMPREDIKSI PERTUMBUHAN PROFIT PERBANKAN (Studi Kasus pada Perusahaan Perbankan yang Terdaftar di BEI Periode 2012 - 2016)
}

\author{
Maisur1, Nyak Umar2 \\ Program Studi Manajemen Fakultas Ekonomi \\ Universitas Jabal Ghafur
}

\begin{abstract}
ABSTRAK
Penelitian ini bertujuan untuk menganalisis pengaruh variabel Return on Asset (ROA), Net Interest Margin (NIM) dan Return on Equity (ROE) terhadap pertumbuhan profit atau laba. Data yang digunakan dalam penelitian ini diperoleh dari laporan keuangan publikasi tahunan perusahaan perbankan yang listing di BEI periode tahun 2012-2016. Jumlah sampel sebanyak 28 perusahaan perbankan yang diambil melalui purposive sampling. Alat analisis data yang digunakan dalam penelitian ini adalah uji statistic dengan metode regresi linear berganda, uji hipotesis menggunakan uji $\mathrm{F}$ dan uji $\mathrm{t}$ serta koefisien determinasi yang sebelumnya telah dilakukan uji asumsi klasik terlebih dahulu. Hasil penelitian menunjukkan bahwa data-data yang digunakan dalam penelitian ini telah memenuhi asumsi klasik yang meliputi: tidak terjadi multikolinearitas, tidak terjadi heteroskadastisitas, tidak terdapat autokolerasi dan data terdistribusi normal. Dari hasil analisis regresi menunjukkan bahwa variabel Return on Asset (ROA) secara parsial berpengaruh positif signifikan terhadap pertumbuhan laba. Sedangkan variabel Net Interest Margin (NIM) dan Return on Equity (ROE) tidak berpengaruh signifikan terhadap laba. Ketiga variabel dalam penelitian ini (ROA, NIM dan ROE) secara simultan berpengaruh terhadap pertumbuhan laba. Kemampuan prediksi dari ketiga variabel adalah sebesar $12,1 \%$.
\end{abstract}

Kata Kunci: Return on Asset (ROA), Net Interest Margin (NIM), Return on Equity (ROE) dan pertumbuhan laba.

\section{Pendahuluan}

Keberadaan perusahaan perbankan atau bank merupakan hal yang paling penting dalam dunia usaha karena bank mampu mendorong perekonomian bangsa. Perbankan yaitu badan usaha yang menghimpun dana dari masyarakat dalam bentuk simpanan dan menyalurkan kepada masyarakat dalam bentuk kredit.

Peranan perbankan sangat penting di dalam perekonomian suatu negara. Sebagai lembaga keuangan, bank adalah hal yang penting bagi kemajuan masyarakat dan sekiranya tidak ada bank, maka tidak akan ada kemajuan seperti saat ini.

Dunia perbankan di Indonesia ini sempat terpuruk terkena krisis moneter yang berkepanjangan. Tapi, akhir-akhir ini mengalami pertumbuhan yang cukup pesat. Persaingan membuat setiap bank untuk mencari keunggulan diri dengan bank-bank lainnya, melalui produkproduk perbankan serta memberikan fasilitasfasilitas, pelayanan yang baik dan kemudahankemudahan bagi setiap nasabahnya.

$$
\text { Bank dalam mempertahankan }
$$

kelangsungan hidup usahanya sangat bergantung pada adanya modal atau investasi dari investor. Investor ini merupakan pihak yang berkelebihan dana yang melakukan investasi dengan harapan akan adanya pendapatan. Dalam hal pendapatan dapat berupa laba (gain) dari kenaikan harga saham ataupun deviden yang diberikan oleh perusahaan. Perusahaan-perusahaan yang membutuhkan investasi/modal dengan menjual sahamnya memerlukan suatu sarana atau wadah yang dapat mempertemukan mereka dengan investor yaitu melalui bursa efek.

Bursa efek merupakan lembaga atau perusahaan yang menyelenggarakan dan menyediakan fasilitas sistem (pasar) untuk mempertemukan penawaran jual dan beli antara berbagai perusahaan atau perorangan yang terlibat dengan tujuan memperdagangkan efek perusahaan-perusahaan yang telah tercatat di bursa efek.

Calon investor apabila ingin menanamkan investasi di Bursa Efek Indonesia memerlukan strategi tertentu dengan metode-metode perhitungan dengan analisis rasio keuangan. Oleh karena itu, investor harus mengikuti perkembangan pada perusahaan perbankan di 
Bursa Efek Indonesia dan dapat mengerti jenisjenis perusahaan yang mempunyai tingkat pertumbuhan laba yang baik atau tidak baik.

Salah satu cara untuk memprediksi laba perusahaan adalah menggunakan rasio keuangan. Analisis rasio keuangan dapat membantu para pelaku bisnis dan pihak pemerintah dalam mengevaluasi keadaan keuangan perusahaan masa lalu, sekarang dan memproyeksi hasil atau laba yang akan datang.

ROA digunakan untuk mengukur tingkat keuntungan perusahaan melalui pendayagunaan seluruh aset perusahaan. Dari rasio ini, kita juga dapat menilai seberapa efisien perusahaan mendayagunakan seluruh asetnya untuk mencapai laba bersih.

Net Interest Margin (NIM) merupakan salah satu indikator yang diperhitungkan dalam penilaian aspek profitabilitas. Di dunia perbankan, Net interest margin (NIM) merupakan salah satu tindakan penting yang harus diperhatikan demi mewujudkan bank yang berkualitas. NIM digunakan sebagai ukuran untuk membedakan antara bunga pendapatan yang diperoleh bank atau mungkin lembaga keuangan dan jumlah bunga yang diberikan kepada pihak pemberi pinjaman. Hasil pengembalian ekuitas atau return on equity atau rentabilitas modal sendiri merupakan rasio untuk mengukur laba bersih sesudah pajak dengan modal sendiri. Rasio ini menunjukkan efisiensi penggunaan modal sendiri. Return on Equity (ROE) digunakan untuk mengukur tingkat imbal-hasil. Investor wajib memperhatikan rasio ini sebab akan menjadi ukuran terhadap keberlangsungan investasi sebagai pemegang saham perusahaan.

Berdasarkan latar belakang di atas, rumusan masalah dalam penelitian ini adalah Apakah a). Return on Asset (ROA) berpengaruh terhadap pertumbuhan profit b). Apakah Net Interest Margin (NIM) berpengaruh terhadap pertumbuhan profit perbankan c).Apakah Return on Equity (ROE) berpengaruh terhadap pertumbuhan profit perbankan

\section{Tinjauan Pustaka}

\section{Pengertian Laporan Keuangan}

Menurut Fahmi (2013:21) laporan keuangan merupakan suatu informasi yang menggambarkan kondisi keuangan suatu perusahaan, dan lebih jauh informasi tersebut dapat dijadikan sebagai gambaran kinerja keuangan perusahaan tersebut.
Menurut Ikatan Akuntan Indonesia (2009:1) laporan keuangan meliputi bagian dari proses laporan keuangan. Laporan keuangan yang lengkap biasanya meliputi neraca, laporan laba-rugi, laporan perubahan ekuitas, laporan perubahan posisi keuangan (yang dapat disajikan dalam berbagai cara misalnya, sebagai laporan arus kas/laporan arus dana), catatan dan laporan lain serta materi penjelasan yang merupakan bagian integral dari laporan keuangan.

\section{Tujuan Laporan Keuangan}

Menurut Ikatan Akuntan Indonesia (2009:3) tujuan laporan keuangan adalah menyediakan informasi yang menyangkut posisi keuangan, kinerja, serta perubahan posisi keuangan suatu perusahaan yang bermanfaat bagi sejumlah besar pemakai dalam pengambilan keputusan ekonomi

Berdasarkan tujuan keuangan dari sumber diatas, maka dapat disimpulkan bahwa tujuan laporan keuangan adalah sarana yang bermanfaat dan dibutuhkan masyarakat karena dapat memberikan informasi yang dibutuhkan para pemakainya dalam dunia bisnis yang dapat menghasilkan keuntungan. Dengan membaca laporan keuangan dengan tepat, seseorang dapat melakukan pengambilan keputusan menyangkut perusahaan yang dilaporkan dan diharapkan akan menghasilkan keuntungan baginya.

Karakteristik Laporan Keuangan

Menurut Sunyoto (2013:11) laporan keuangan sebagai suatu sumber informasi harus memenuhi beberapa persyaratan agar kebijaksanaan yang diambil berdasarkan informasi itu tidak menyesatkan. Adapun syaratsyaratnya sebagaimana disebutkan dalam exposure draft Prinsip Akuntansi Indonesia (Bambang S.,1985) meliputi:

a). Relevan

b). Dapat dimengerti

c). Daya uji

d). Netral

e). Tepat Waktu

f). daya banding

g). Lengkap

\section{Pengertian Analisis Rasio Keuangan}

Adapun pengertian rasio keuangan menurut Kasmir (2009:104) Rasio keuangan merupakan indeks yang menghubungkan dua angka akuntansi dan diperoleh dengan membagi 
satu angka dengan angka yang lainnya dalam satu periode maupun beberapa periode.

Menurut Jumingan (2011:242) analisis rasio merupakan analisis dengan membandingkan satu pos dengan pos laporan keuangan lainnya, baik secara individu maupun bersama-sama guna mengetahui hubungan diantara pos tertentu, baik dalam neraca maupun laporan laba rugi.

Menurut Fahmi (2012:58) bagi investor ada tiga rasio keuangan yang paling dominan yang dijadikan rujukan untuk melihat kondisi kinerja suatu perusahaan, yaitu:

1. Rasio likuiditas (Liquidity ratio)

2. Rasio solvabilitas (Solvability ratio)

3. Rasioprofitabilitas (Profitability ratio)

\section{Return On Asset (ROA)}

Menurut Tambunan (2013:205) ROA adalah rasio yang digunakan untuk mengukur tingkat keuntungan perusahaan melalui pendayagunaan seluruh aset perusahaan. Menurut Fahmi (2012:82) ROA adalah rasio yang melihat sejauh mana investasi yang telah ditanamkan maupun memberikan pengembalian keuntungan sesuai yang diharapkan.

Rumus untuk mencari return on asset adalan sebagai berikut:

$$
\mathrm{ROA}=\frac{\text { Earningaftertax }}{\text { Tottal Asset }} \times 100 \%
$$

Jadi, ROA merupakan rasio yang mengukur kemampuan perusahaan dalam memanfaatkan aktiva yang dimiliki perusahaan untuk menghasilkan laba dengan cara membandingkan pendapatan dengan aktiva yang dipakai perusahaan.

\section{Net Interest Margin (NIM)}

Menurut Haryani (2010:54), Rasio ini digunakan untuk mengukur kemampuan manajement bank dalam mengelola aktiva produktifnya untuk menghasilkan pendapatan bunga bersih.

Rumus Net Interest Margin (NIM) menurut Surat Edaran Bank Indonesia No.13/24/DPNP tanggal 25 Oktober 2011 adalah sebagai berikut:

NIM $=($ Pendapatan Bunga Bersih)/(Aktiva Produktif)x100\%

\section{Return on Equity (ROE)}

Menurut Fahmi (2012:82) "ROE disebut juga dengan laba atas equity". Dibeberapa referensi disebut juga dengan rasio total asset turnover atau perputaran total asset. Rasio ini mengkaji sejauh mana suatu perusahaan mempergunakan sumber daya yang dimiliki untuk mampu memberikan laba atas ekuitas. berikut:

$$
\text { Rasio ini dapat dirumuskan sebagai }
$$

$$
\mathrm{ROE}=\frac{\text { Earning after } \text { tax }}{\text { Equity }} \times 100 \%
$$

\section{Laba (Profit)}

Menurut Hanafi (2010:32) laba merupakan ukuran keseluruhan prestasi perusahaan, yang didefinisikan sebagai berikut: Laba = Penjualan - Biaya. Pengertian laba menurut Harahap (2008:113) laba adalah kelebihan penghasilan diatas biaya selama satu periode akuntansi.

Pertumbuhan laba merupakan kenaikan laba atau penurunan laba per tahun. Untuk mengetahui perubahan laba yang terjadi pada perusahaan akan digunakan rumus sebagai berikut :

Pertumbuhan Laba $=\frac{Y_{t-Y_{t-1}}}{Y_{t-1}}$

\section{Metode Penelitian}

Jenis data yang digunakan dalam penelitian ini adalah data kuantitatif atau sekunder, yaitu data yang diperoleh dalam bentuk angka-angka yang dapat dihitung yang berkaitan dengan masalah yang diteliti. Data yang diharapkan berupa data laporan keuangan tahunan perusahaan perbankan yang terdaftar di BEI periode 2012-2016.

\section{Populasi dan Sampel}

Populasi dalam penelitian ini yaitu seluruh perusahaan perbankan yang terdaftar di BEI, yang berjumlah 43 perusahaan. Pada penelitian ini menggunakan purposive sampling dengan kriteria di atas, dan setelah data perusahaan didokumentasikan sesuai dengan kriteria yang telah ditetapkan, maka diperoleh sampel dalam penelitian ini yaitu sebanyak 28 perusahaan dengan periode penelitian yaitu 2012-2016.

\section{Jenis dan Sumber Data}

Jenis data yang digunakan dalam penelitian ini adalah data kuantitatif atau sekunder, yaitu data yang diperoleh dalam 
bentuk angka-angka yang dapat dihitung yang berkaitan dengan masalah yang diteliti. Data yang diharapkan berupa data laporan keuangan tahunan perusahaan perbankan yang terdaftar di BEI periode 2012-2016.

Sumber data yang digunakan berupa laporan keuangan tahunan yang telah dikeluarkan oleh perusahaan perbankan yang terdaftar di BEI dari tahun 2012-2016 yang diperolehdari website dengan cara mengunduh laporan keuangan melalui situs http:///www.idx.co.id.

\section{Alat Analisis Data}

Penelitian ini menggunakan analisis regresi berganda (Multiple Regression Analysis). Analisis regresi linear berganda digunakan untuk menaksirkan bagaimana keadaan (naik turunnya) variabel dependen, bila dua atau lebih variabel dependen sebagai faktor pedikator dimanipulasi (dinaik turunkan nilainya). (Sugiyono, 2012:277)

Dalam penelitian ini, analisis regresi linier berganda ini digunakan untuk menguji pengaruh rasio keuangan terhadap pertumbuhan laba. Model dalam penelitian ini adalah :

$\mathrm{Y}=\alpha+\mathrm{b} 1 \mathrm{X} 1+\mathrm{b} 2 \mathrm{X} 2+\mathrm{b} 3 \mathrm{X} 3+\mathrm{e}$

Keterangan :

$\mathrm{Y}=$ PertumbuhanLaba

$\mathrm{A}=$ Konstanta

$\mathrm{b}=$ Koefisien dari masing-masing variabel

$\mathrm{X} 3=$ Return on Equity (ROE)

$\mathrm{e}=$ Koefisien error (variabel penganggu) $\mathrm{X} 1=$ Return on Asset (ROA)

$\mathrm{X} 2=$ Net Interest Margin (NIM)

\section{Hasil Penelitian Dan Pembahasan \\ Hasil Regresi Linear Berganda}

Analisis ini dilakukan untuk mengetahui apakah ada pengaruh yang siknifikan dari variable independen dependen, maka digunakan model regresi berganda. Berdasarkan persamaan regresi yang sudah di output SPSS menghasilkan data sebagai berikut:

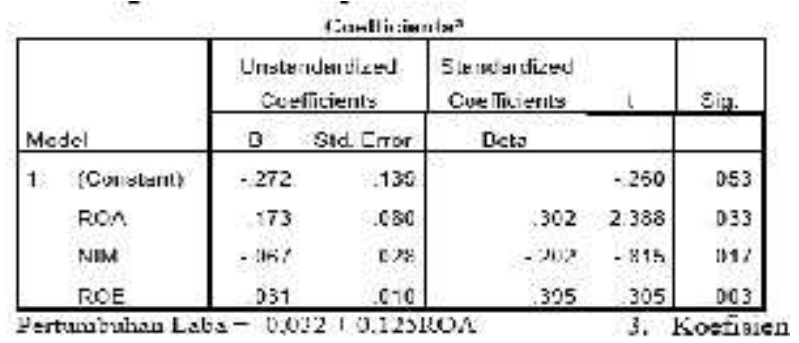

Pertumbuhan Laba $=-0,032+0,125 \mathrm{ROA}-$ $0,021 \mathrm{NIM}+0,002 \mathrm{ROE}$

Pertumbuhan profit $=-0,272+0,173 \mathrm{ROA}-$ $0,067 \mathrm{NIM}+0,031 \mathrm{ROE}$

Berdasarkan model persamaan regresi maka hasilnya sebagai berikut :

1. Persamaan regresi linear berganda diatas, diketahui mempunyai konstanta sebesar 0,272 dengan tanda negatif. Sehingga besaran konstanta menunjukkan bahwa jika variabel (ROA, NIM dan ROE) diasumsikan konstan, maka variabel dependen yaitu pertumbuhan profit akan turun sebesar 0,272\%

2. Koefisien variabel ROA sebesar 0,173 berarti setiap kenaikan ROA sebesar $1 \%$ akan menyebabkan kenaikan profit sebesar $0,173 \%$

3. Koefisien variabel NIM sebesar $-0,067$ artinya jika NIM naik $1 \%$ maka penurunan profit sebesar 0,067\%

4. Koefisien variabel ROE sebesar 0,031 artinya jika ROE naik $1 \%$ maka pertumbuhan profit naik $0,031 \%$.

\section{Hasil Uji Hipotesis \\ Uji parsial (Uji t)}

Berdasarkan hasil perhitungan menggunakan SPSS versi 22, dapat dilihat bahwa semua variabel independen (ROA, NIM dan ROE ) berpengaruh secara signifikan terhadap variabel dependen yaitu pertumbuhan profit dengan tingkat signifikan $0,033,0,017$ dan 0,003 lebih kecil dari 0,05.

1. Hasil Uji Hipotesis Pengaruh ROA (X1) Terhadap Pertumbuhan Profit (Y).Dari hasil penelitian diperoleh koefisien transformasi regresi untuk variabel ROA sebesar 0,173 yang berpengaruh secara positif terhadap pertumbuhan profit. Selain itu, memiliki nilai signifikan sebesar 0,033 dimana nilai ini signifikan karena lebih kecil dari 0,05. Artinya, ROA berpengaruh secara signifikan terhadap pertumbuhan profit.

2. Hasil Uji Hipotesis Pengaruh NIM (X2) terhadap Pertumbuhan Profit Berdasarkan persamaan regresi terlihat bahwa koefisien untuk variabel ini bernilai negatif $-0,067$ sehingga dapat diartikan bahwa pengaruh yang diberikan oleh NIM terhadap pertumbuhan profit adalah negatif. Koefisien regresi sebesar $-0,067$ berarti setiap kenaikan NIM sebesar $1 \%$ akan 
menurunkan laba sebesar $0,067 \%$. Pada hasil pengujian parsial (uji t) terhadap profit menunjukkan nilai signifikan sebesar 0,017 artinya nilai signifikannya dibawah 0,05 . menurunnya tingkat profit yang diperoleh.

3. Hasil Uji hipotesis Pengaruh ROE (X3) Terhadap Pertumbuhan Laba (Y) Berdasarkan persamaan regresi terlihat bahwa koefisien untuk variabel ini bernilai 0,031 yang berpengaruh positif terhadap pertumbuhan profit. Hasil pengujian parsial menunjukkan nilai signifikansi sebesar 0,003 yang artinya variabel ROE berpengaruh secara signifikan terhadap perumbuhan profit. Kondisi ini mengandung arti semakin tinggi nilai ROE maka semakin tinggi laba yang diperoleh perusahaan. Hal ini disebabkan ROE mengindikasikan tingkat pengelolaan modal yang diinvestasikan oleh pemilik perusahaan dan investor lain.

4. Hasil Uji Hipotesis Variabel $\mathrm{X}$ yang Memiliki Pengaruh Paling Dominan terhadap Variabel Y (Pertumbuhan Profit) adalah

5. ROA Untuk menentukan nilai $X$ yang paling dominan berengaruh terhadap variabel $\mathrm{Y}$ yakni melihat variabel $\mathrm{X}$ yang memiliki nilai paling besar pada kolom $\mathrm{B}$. Berdasarkan Tabel 4.6 variabel ROA memiliki nilai paling besar yaitu 0,173 .

\section{Kesimpulan}

Berdasarkan analisis data dan pembahasan hasil penelitian, dapat diambil kesimpulan sebagai berikut:

1. Dari hasil penelitian ketiga variabel (ROA, NIM dan ROE) secara bersama-sama berpengaruh signifikan terhadap pertumbuhan laba. Artinya, setiap perubahan yang terjadi pada variabel independen yaitu ROA, NIM dan ROE secara simultan atau bersama-sama akan berpengaruh pada pertumbuhan laba.
2. Secara parsial variabel ROA, NIM, dan ROE memiliki pengaruh terhadap pertumbuhan laba. Berdasarkan hasil penelitian:

a. Variabel ROA berpengaruh positif dan signifikan terhadap pertumbuhan laba.

b. VariabelNIM berpengaruh negative dan tidak signifikan terhadap pertumbuhan laba.

c. Variabel ROE berpengaruh positif tetapi tidak signifikan terhadap pertumbuhan laba

d. Variabel $\mathrm{X}$ yang memiliki pengaruh paling dominan tehadap variabel $\mathrm{Y}$ (pertumbuhan laba) adalah ROA

\section{DAFTAR PUSTAKA}

Hanafi, Mahmud M. 2010. Dasar-Dasar Manajemen Keuangan. Jakarta: Balai Pustaka

Haryani, Iswi. 2010. Restrukturisasi dan Penghapusan Kredit Macet. Jakarta: PT Elex Media Komputindo

Ikatan Akuntan Indonesia. 2009. Pernyataan Standar Akuntansi Keuangan. Jakarta: Salemba Empat.

Fahmi, Irham. 2012. Pengantar Manajemen Keuangan. Jakarta: Bumi Aksara

Jumingan. 2011. Analisis Laporan Keuangan. Jakarta: Bumi Aksara

Kasmir. 2010. Analisis Laporan Keuangan. Jakarta: PT Raja Grafindo Persada20082012. Skripsi. Semarang: Fakultas Ekonomi Universitas Dipenogoro

Sugiyono. 2012. Memahami Penelitian Kuantitatif Bandung: Alfabeta.

Sunyoto, Danang. 2013. Analisis Laporan Keuangan Untuk Bisnis Teori dan Kasus. Buku Seru

Tambunan, Andy Porman. 2013. Analisis Saham Perdana (IPO). Jakarta: Elex Media Komputindo. 